\title{
Biolistic-mediated genetic transformation of cowpea (Vigna unguiculata) and stable Mendelian inheritance of transgenes
}

\author{
Nayche L. Ivo • Cristina P. Nascimento • \\ Lívia S. Vieira - Francisco A. P. Campos • \\ Francisco J. L. Aragão
}

Received: 26 May 2008/Accepted: 12 June 2008/Published online: 28 June 2008

(C) Springer-Verlag 2008

\begin{abstract}
We describe a novel system of exploiting the biolistic process to generate stable transgenic cowpea (Vigna unguiculata) plants. The system is based on combining the use of the herbicide imazapyr to select transformed meristematic cells after physical introduction of the mutated ahas gene (coding for a mutated acetohydroxyacid synthase, under control of the ahas $5^{\prime}$ regulatory sequence) and a simple tissue culture protocol. The gus gene (under control of the act 2 promoter) was used as a reporter gene. The transformation frequency (defined as the total number of putative transgenic plants divided by the total number of embryonic axes bombarded) was $0.90 \%$. Southern analyses showed the presence of both ahas and gus expression cassettes in all primary transgenic plants, and demonstrated one to three integrated copies of the transgenes into the genome. The progenies (first and second generations) of all self-fertilized transgenic lines revealed the presence of the transgenes (gus and ahas) cosegregated in a Mendelian fashion. Western blot analysis revealed that the GUS protein expressed in the transgenic plants had the same mass and isoelectric point as the bacterial native protein. This is the first report of biolisticmediated cowpea transformation in which fertile transgenic
\end{abstract}

Communicated by D. Somers.

N. L. Ivo · C. P. Nascimento · L. S. Vieira · F. J. L. Aragão ( $\square)$ Embrapa Recursos Genéticos e Biotecnologia, PqEB W5 Norte, Asa Norte, Brasília, DF 70770-200, Brazil

e-mail: aragao@cenargen.embrapa.br

F. A. P. Campos

Departamento de Bioquímica e Biologia Molecular,

Universidade Federal do Ceará, Campus do Pici, Bloco 907,

Fortaleza, CE 60451-970, Brazil plants transferred the foreign genes to next generations following Mendelian laws.

Keywords Gene expression - Gene transfer - Imazapyr · Transgene $\cdot$ Transgenic plant

\section{Introduction}

Cowpea [Vigna unguiculata (L.) Walp.] is widely grown in Africa, Latin America, Southeast Asia and southwestern regions of North America, with a world annual production of about 3.9 million metric tons (FAOSTAT 2006). For economic and cultural reasons, cowpea plays an important role in human nutrition since it is a rich source of protein, calories, certain minerals and vitamins (Obatolu 2003; Phillips et al. 2003).

Cowpea is highly susceptible to many viral diseases, such as Cowpea aphid borne mosaic virus, Cowpea severe mosaic virus, Blackeye cowpea mosaic virus and Cowpea yellow mosaic virus, and it is the host for a wide range of insect pests, notably flower bud thrips, pod borers, leaf beetles, pod suckers, aphids and leaf hoppers, which seriously limits the realization of its yield potential, estimated at 1.5-3.0 ton $\mathrm{ha}^{-1}$ (Murdock 1992; Aliyu 2007; Taiwo et al. 2007). Durable and adequate levels of resistance to these viruses and pests are lacking in the primary gene pool, but are available in distant wild species, which present barriers for gene transfer through conventional crossing techniques (Gomathinayagam et al. 1998). In addition, limited genetic diversity in cowpea breeding programs is of special concern because cowpea appears to have lower inherent genetic diversity than other cultivated crops as a result of a hypothesized single domestication event (Fang et al. 2007). Consequently, the transfer of virus 
and insect resistance genes by genetic engineering could potentially aid plant breeders in overcoming these constraints.

During the last two decades, several investigations have attempted to develop efficient systems for the introduction of exogenous genes into the cowpea genome. However, the protocols published to date have failed to produce a system that is both simple to execute and variety independent. Garcia et al. (1986, 1987) were the first to investigate whether cowpea was susceptible to Agrobacterium tumefaciens infection and demonstrated that foreign genes could be stably introduced and expressed in cowpea cells. Although transgenic kanamycin-resistant calli were obtained, no plants could be regenerated. Penza et al. (1991) used mature cowpea embryos as a target for genetic transformation by A. tumefaciens and were able to regenerate putatively transgenic plants. However, genetic evidence of transgene integration was not presented. The first production of transgenic cowpea plants was reported by Muthukumar et al. (1996). These authors co-cultivated detached cotyledonary explants with A. tumefaciens, followed by transfer of the explants to a selective medium, and recovered hygromycin-resistant shoots that grew to maturity and set seed. Nevertheless, none of the seeds germinated and no evidence of transgene transmission to the progeny was obtained. Recently, two Agrabacteriummediated transformation systems have been developed. Popelka et al. (2006) obtained transgenic plants with a frequency of transformation of $0.15 \%$. Transgenic lines transmitted the transgene (bar gene) to their progenies following Mendelian laws (Popelka et al. 2006). Chaudhury et al. (2007) used cotyledonary node explants to generate fertile transgenic plants with an efficiency of $0.76 \%$. Transgenic plants were selected with kanamycin and they inherited the transgenes in Mendelian fashion in the first generation. Nevertheless, these transformation systems are laborious, time consuming, likely to be genotype-dependent and present low frequency of germ line transformation.

Methods of cowpea transformation via direct DNA delivery have also been reported. The transient expression of reporter genes in cowpea seedlings following the electroporation of zygotic embryos with plasmid DNA harboring the chimeric gus gene has been demonstrated (Penza et al. 1992; Akella and Lurquin 1993), but so far no stably transformed plants have been obtained. Ikea et al. (2003) were able to generate transgenic cowpea plants after particle bombardment of embryonic axes. However, the transgenes were transmitted to only a small proportion of the progeny and no evidence for stable integration was presented. In addition, the tissue culture protocol used was time consuming, involving several treatments and medium transfers of the bombarded embryos, prior to achieving putative transgenic plantlets.

Despite all efforts, the genetic manipulation of cowpea is still not trivial and regeneration and transformation systems need to be improved (Somers et al. 2003; Aragão and Campos 2007). Here we describe a novel system for biolistic-mediated genetic transformation of cowpea, which followed a transgene transmission through two generations. This system is based on the introduction of a mutant ahas gene (coding for acetolactate synthase) and selection with imazapyr, a herbicidal molecule that is capable of systemically translocating and concentrating in the apical meristematic region of the plant. We believe that this new technology should facilitate detailed genomics studies, as well as the development of transgenic cowpea varieties with improved agricultural characteristics.

\section{Materials and methods}

\section{Electron microscopy}

The apical region morphology of cultivars Paraguaçu, Gurguéia, MNC99-5417-8, Guariba, Vita 7, Pitiúba, Rouxinol, CE-315, CE-11 and MNC01-623-51 was studied under the scanning electron microscope. Embryonic axes were removed from seeds that had been soaked in distilled water for $16 \mathrm{~h}$. Fifty embryonic axes for each cultivar were prepared as described by (Aragão and Rech 1997) and observed in a Zeiss DSM 962 SEM operating at $15 \mathrm{kV}$.

\section{Determination of imazapyr selection dosage}

Hand-harvested mature seeds (cv Paraguaçu, Pitiúba, Rouxinol and CE-11) were surface-sterilized in $70 \%$ ethanol for $1 \mathrm{~min}$ followed by immersion in $1 \%$ sodium hypochlorite for $20 \mathrm{~min}$ and then rinsed three times in sterile distilled water. The seeds were then soaked in distilled water for 18-20 h. The embryonic axes were excised from seeds, and the shoot apical meristems were exposed by removing the primary leaves and leaf primordia under a stereomicroscope. Explants were transferred to MS medium containing $3 \%$ glucose, $5 \mathrm{mg} \mathrm{L}^{-1}$ benzylaminopurine (BAP), 0.6\% agar and 0, 50, 100, 150, 200, 300 or $400 \mathrm{n} M$ imazapyr (2-[4.5-dihydro-4-methylethyl)-5-oxo-1H-imidazol-2-yl]-3-pyridinecarboxylic acid). The $\mathrm{pH}$ was adjusted to 5.7 , prior to autoclaving. After 3 weeks, explants were analyzed for the presence of elongated shoots $(3 \mathrm{~cm}$ in length). Each treatment containing ten embryonic axes was performed in triplicate. The experiment was repeated twice. 
Cowpea transformation

Embryonic axes (cv. CE-11) were prepared as described above and positioned in the bombardment medium (MS basal salts medium, $3 \%$ sucrose and $0.8 \%$ phytagel Sigma, $\mathrm{pH}$ 5.7) with the shoot apical region directed upwards in 5$\mathrm{cm}$ culture dishes containing $12 \mathrm{ml}$ culture medium. The bombardment was conducted as previously described (Aragão et al. 2000; Rech et al. 2008) with the plasmid pAG1, which contains the mutated ahas gene from Arabidopsis thaliana (Rech et al. 2008) and the gus gene under control of the act2 promoter (act2p) (Fig. 1).

After bombardment, the embryonic axes were transferred to the selection and shoot induction medium (MS basal salts medium, supplemented with $5 \mathrm{mg} \mathrm{L}^{-1} \mathrm{BAP}, 3 \%$ sucrose, $200 \mathrm{n} M$ imazapyr and $0.6 \%$ agar, Sigma, pH 5.7) in baby-food jars containing $15 \mathrm{ml}$ of the culture medium, cultured at $26^{\circ} \mathrm{C}$ in the dark for 2 days, and then transferred to light with a 16 -h photoperiod $\left(50 \mu \mathrm{mol} \mathrm{m} \mathrm{m}^{-2} \mathrm{~s}^{-1}\right)$. As soon as the shoots derived from the embryonic axes were $2-3 \mathrm{~cm}$ in length, a 1-mm-long section was removed from each leaf for analysis of GUS ( $\beta$-glucoronidase) expression (Jefferson 1987). GUS-positive explants were transferred to MS medium supplemented with 3\% sucrose, $0.6 \%$ agar and $3 \mathrm{~g} \mathrm{~L}^{-1}$ activated charcoal for rooting. Rooted explants were individually transferred to a plastic pot containing 0.2 $\mathrm{dm}^{3}$ of an autoclaved mixture of fertilized soil:vermiculite (1:1), covered with a transparent plastic bag sealed with a rubber band and maintained in a greenhouse. After 1 week, the rubber band was removed. After an additional week,

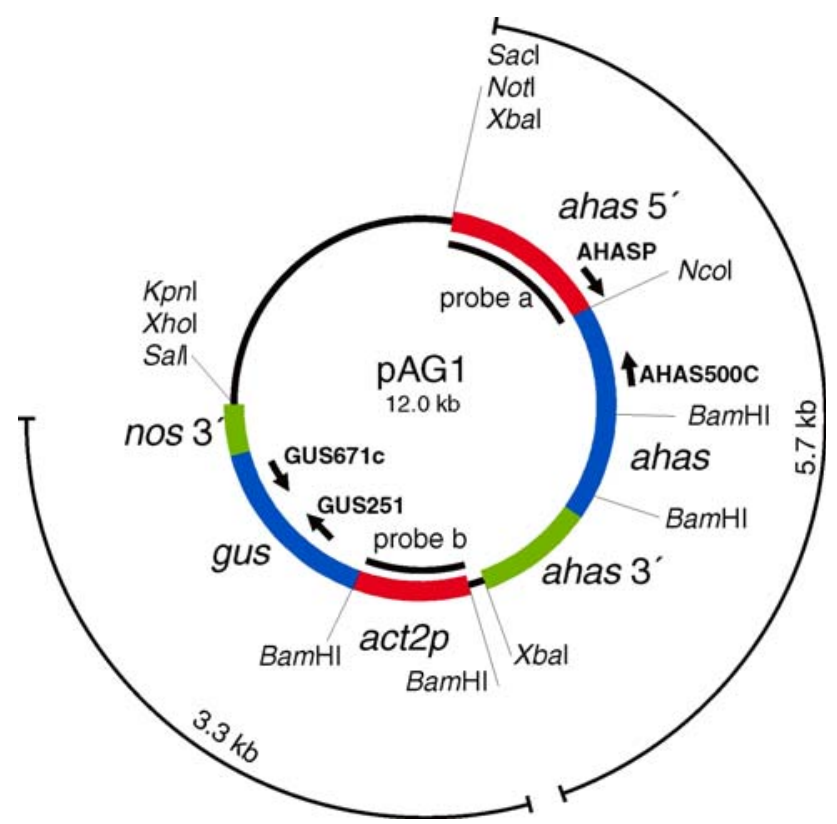

Fig. 1 Diagram of the plasmid vector pAG1 used for cowpea transformation. Small arrows indicate primers used for PCR screening. Solid bars represent probes used for Southern blot analysis the plastic bag was also removed. As soon as the acclimatized plantlets reached approximately $10 \mathrm{~cm}$ in length, they were transferred to a pot containing $5 \mathrm{dm}^{3}$ of fertilized soil and allowed to set seeds.

\section{Screening of transgenic plants by PCR}

DNA was isolated from leaf disks according to Edwards et al. (1991). Each PCR reaction was carried out in $25 \mu \mathrm{l}$ aliquots containing $10 \mathrm{mM}$ TRIS- $\mathrm{HCl}(\mathrm{pH} 8.4), 50 \mathrm{mM}$ $\mathrm{KCl}, 2 \mathrm{mM} \mathrm{MgCl} 2,160 \mu \mathrm{M}$ of each dNTP, $200 \mathrm{n} M$ of each primer, $2 \mathrm{U}$ of $\mathrm{Taq}$ polymerase (Phoneutria, Belo Horizonte, Brazil) and 20-30 ng of genomic DNA. The primers AHASP (5'-ACTAGAGATTCCAGCGTCAC- $3^{\prime}$, within the ahas promoter) and AHAS500C (5'-GTGGCTATACAGATACCTGG- $3^{\prime}$, within the ahas coding sequence) were utilized to amplify a $685 \mathrm{bp}$ sequence. The primers GUS251 (5'-TTGGGCAGGCCAGCGTATCGT- $\left.3^{\prime}\right)$ and GUS671c (5'-ATCACGCAGTTCAACGCTGAC-3') were utilized to amplify a $420 \mathrm{bp}$ sequence. The mixture was overlaid with mineral oil, denatured for $5 \mathrm{~min}$ at $95^{\circ} \mathrm{C}$ in an MJ thermal cycler (USA) and amplified for 35 cycles $\left(95^{\circ} \mathrm{C}\right.$ for $1 \mathrm{~min}, 55^{\circ} \mathrm{C}$ for $1 \mathrm{~min}, 72^{\circ} \mathrm{C}$ for $1 \mathrm{~min}$ ) with a final cycle of $7 \mathrm{~min}$ at $72^{\circ} \mathrm{C}$. The reaction mixture was then loaded onto $1 \%$ agarose gel and visualized under UV light following ethidium bromide staining.

\section{Southern blot analysis}

Genomic DNA was isolated using the DNeasy Plant Mini Kit (Qiagen). Southern blotting was carried out as described by Sambrook and Russell (2001). Genomic DNA (15 $\mu \mathrm{g}$ ) was digested with $\mathrm{NcoI}$ or $\mathrm{XbaI}$, separated on $1 \%$ agarose gel and transferred to a nylon membrane (Hybond $\mathrm{N}+$, Amershan Pharmacia Biotech). Hybridization was carried out using the $5^{\prime}$ region of the ahas gene (probe a) or the act 2 promoter (probe b), labeled with ${ }^{\alpha} 32 \mathrm{P}$ dCTP (1.13 $\times 10^{14} \mathrm{~Bq} \mathrm{~mol}^{-1}$ ) using a random primer DNA labeling kit (Amersham Pharmacia Biotech) according to the manufacturer's instructions. The bands were visualized with a fluorescent image analyzer (FLA-3000) (FUJIFILM).

Protein extraction, two-dimensional electrophoresis and Immunoblotting analysis

Mature leaves from transformed and control plants were freeze-dried and a fine powder was obtained by grinding in a coffee mill and sieving through a 100-mesh metal sieve. Protein extraction was performed as described by Vasconcelos et al. (2005), and the evaluation of protein content in the extracts was assessed by the Bradford method (Bradford 1976). For two-dimensional electrophoresis, 11-centimeter Immobiline DryStrips, pH 4-7 
(Amersham) were rehydrated overnight with rehydration buffer ( $7 \mathrm{M}$ urea, $2 \mathrm{M}$ thiourea, $1 \%$ triton X-100, $0.5 \%$ Pharmalyte 3-10, $65 \mathrm{mM}$ DTT) containing the protein extract. Running was performed in a Multiphor II IEF system from Amersham Pharmacia Biotech. Electrical conditions were as described by the supplier. After the firstdimensional run, the IPG gel strips were sealed in plastic wrap and frozen at $-80^{\circ} \mathrm{C}$ or incubated at room temperature to equilibrate the strips in $3 \mathrm{ml}$ of equilibration buffer (50 mM Tris, 30\%, 6 M urea, 2\% SDS and traces of Bromophenol blue) containing $57.8 \mathrm{mg}$ of DTT, prior to separation in the second dimension. The second dimension electrophoresis was performed in a vertical system with a uniform $15 \%$ separating gel $(14 \times 14 \mathrm{~cm})$, at $25^{\circ} \mathrm{C}$. After 2-DE, the proteins were transferred to a nitrocellulose membrane using a TE Series Transfor Electrophoresis Unit (Hoeffer Scientific Instruments, San Francisco, CA, USA). This membrane was probed with polyclonal antibodies raised against a synthetic peptide corresponding to amino acids 589-603 at the C-terminus of E. coli GUS, conjugated to KLH [produced by Sigma Aldrich (Product number G5545)], and detected with alkaline phosphataseconjugated anti-goat IgG.

\section{Progeny analysis}

The analysis of the R1 generation was carried out by amplifying the introduced foreign ahas gene by PCR and by the GUS histochemical assay analysis of leaves of selfpollinated plants. The GUS histochemical assay was performed as described by Jefferson (1987). Chi-square $\left(\chi^{2}\right)$ analyses (Steel and Torrie 1980) were performed to determine if the observed segregation ratio was consistent with a Mendelian ratio in the $\mathrm{R}_{1}$ generation.

\section{Results}

The morphology of the vegetative shoot of ten cowpea cultivars was analyzed. All revealed the apical meristematic region to be almost completely covered by the leaf primordia. Only a small area of the central region could be visualized (Fig. 2). Consequently, it was necessary to remove the primary and primordial leaves in order to expose the meristematic area to the DNA-coated microparticle (Fig. 2).

In order to evaluate the effect of imazapyr on shoot formation and elongation, a dose-response curve was calculated. We observed that imazapyr inhibited shoot elongation in a dose-dependent manner up to approximately $200 \mathrm{nM}$, when shoot elongation was completely suppressed in all of the cultivars which were tested (cv Paraguaçu, Pitiúba, Rouxinol and CE-11) (Fig. 3). In
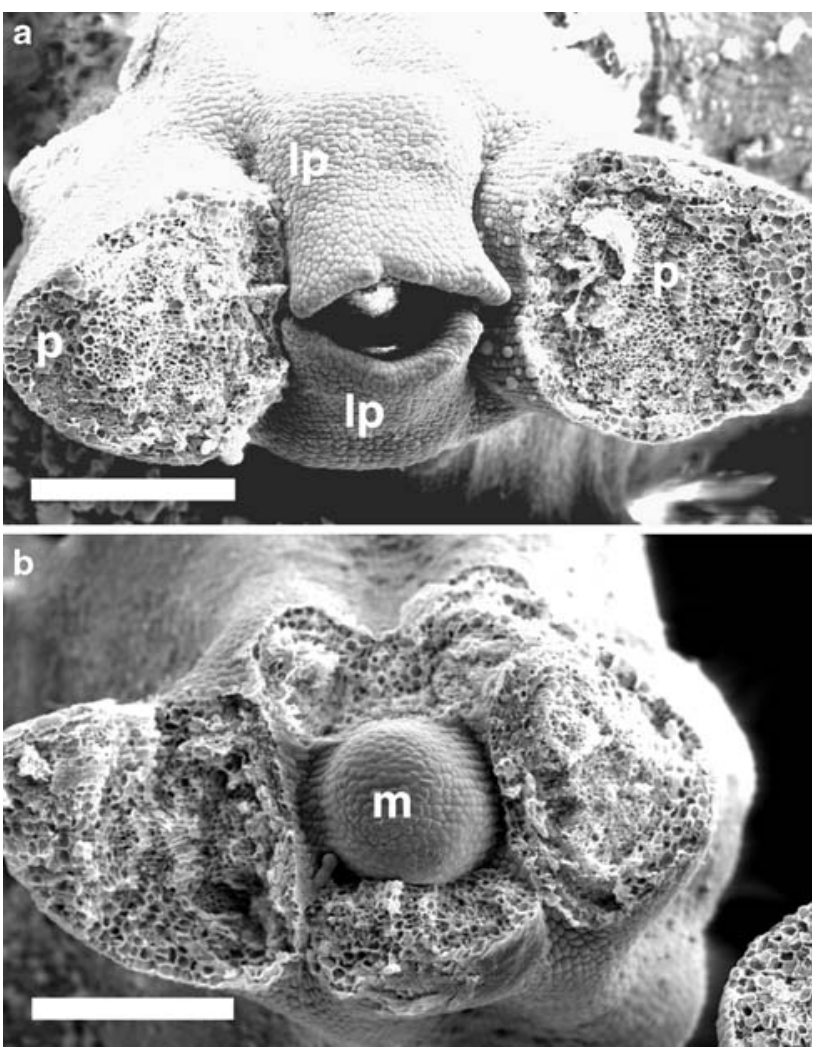

Fig. 2 Scanning electron micrographs showing the morphology of the cowpea embryonic apex. a The apical region after the removal of the primary leaves $(p)$. b The leaf primordia $(l p)$ are removed to expose the apical meristematic region $(m)$. Bars represent $200 \mu \mathrm{m}$

concentrations of $300 \mathrm{nM}$ or $400 \mathrm{nM}$ no elongated shoots were observed (data not shown).

Apical regions of cowpea embryonic axes (cv. CE-11) were bombarded with the plasmid pAG1 (Fig. 1). Nine independent bombardment experiments were carried out, in which 552 embryonic axes were bombarded. Following bombardment, embryonic axes were cultured in selection and multiple shoot induction medium. Twenty-four hours after bombardment, the majority of the embryonic axes analyzed (ca. 20) showed extensive gus gene expression within the apical region (Fig. 4). After 2 weeks in culture under selection with $200 \mathrm{nM}$ imazapyr, elongated shoots (about $2 \mathrm{~cm}$ long) were observed. Typically, a total of 3-4 shoots were induced from each bombarded embryonic axis, but only $2 \%$ elongated. Out of 13 elongated shoots, PCR and GUS histochemical analyses confirmed the presence of both ahas and gus transgenes in five elongated shoots, generated from independent explants. About $61 \%$ of elongated shoots were escapes. However, no escapes were observed under higher selection pressure $(\geq 300 \mathrm{nM}$ imazapyr), but the number of plants obtained was much lower and no transgenic plants were observed (data not shown). The transformation frequency (defined as the total number 

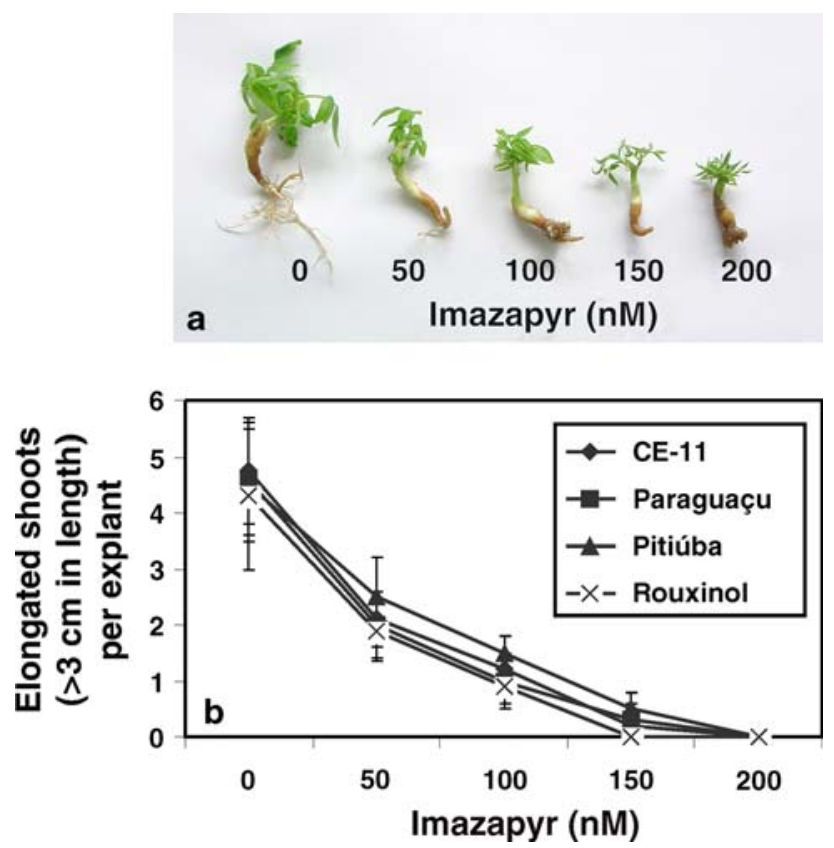

Fig. 3 Effect of imazapyr on shoot formation and elongation in the apical region of cowpea embryonic axes, after 3 weeks cultivation on MS medium containing $3 \%$ glucose and $5 \mathrm{mg} \mathrm{L}^{-1} 1$ BAP. a Shoot formation and elongation suppression observed for cv. CE-11. b Effect of imazapyr on shoot survival and elongation for $\mathrm{cv}$. Paraguaçu, Pitiúba, Rouxinol and CE-11. Each point represents the mean of $n=90$ samples, error bars represent SEM

of putative transgenic plants divided by the total number of embryonic axes bombarded) was $0.90 \%$. All plantlets that developed vigorous roots were acclimatized and transferred to soil. Histochemical GUS assays performed on leaf and floral tissues from all transgenic plants revealed intense $\beta$-glucuronidase activity (Fig. 4).

Southern blot analyses of genomic DNA isolated from the $\mathrm{T}_{0}$ generation transgenic cowpea plants were carried out to evaluate the integration of the introduced ahas and gus cassettes. Southern analyses with the genomic DNA digested with $X b a$ I followed by hybridization to ahas $5^{\prime}$ fragment (probe a) showed the presence of a complete ahas cassette (denoted by the $5.7 \mathrm{~kb}$ fragment) in all $\mathrm{T}_{0}$ generation lines analyzed (Fig. 5). Since the plasmid pAG1 has a unique NcoI restriction site (Fig. 1), Southern analysis carried out with genomic DNA digested with $\mathrm{Nco}$ I followed by hybridization to probe ' $a$ ' allowed us to estimate that the copy number of ahas cassette was one for lines 5.1, 5.2 and 5.5, three for line 5.3 and two for line 5.4 (Fig. 5). Additionally, Southern analyses was carried out with the genomic DNA digested with $X b a \mathrm{I}$ and $N c o \mathrm{I}$, and probed with the $a c t 2 p$ fragment (probe b). Results showed that line 5.3 presented one incomplete gus expression cassette because a fragment smaller than $3.3 \mathrm{~kb}$ was observed (which is the size of the gus cassette) for the DNA digested with XbaI (Fig. 5). Additionally, the fact that only two
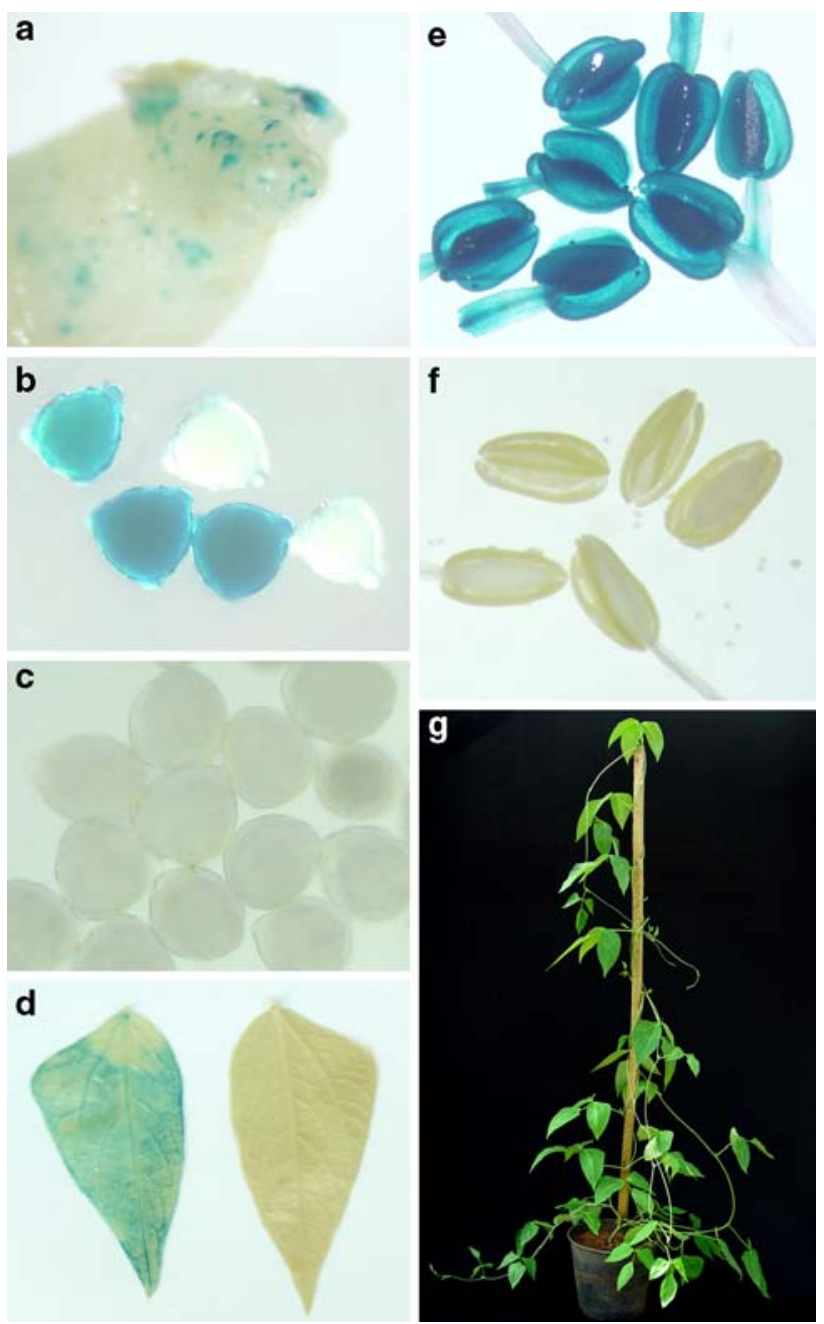

Fig. 4 Cowpea transformation. $a$ Embryonic axis expressing the gus gene in the meristematic region $24 \mathrm{~h}$ after bombardment; b microspores from a transgenic line showing gus gene segregation; c microspores from a non-transgenic line; $\mathbf{d}$ leaves from control (right) and transgenic (left) plants expressing the gus gene; e anthers from transgenic and $\mathbf{f}$ non-transgenic plant; $\mathbf{g}$ a primary transgenic plant after acclimatization

bands were observed for line 5.3 and only one band was found for line 5.4, suggests that these lines have only one functional gus cassette (Fig. 5). DNA isolated from nontransformed plants did not hybridize with the $5^{\prime}$ ahas probe (Fig. 5).

A Western blot analysis was carried out with line 5.5 to detect the GUS protein within the total proteins isolated from leaf and fractionated by $2 \mathrm{D}$ gel electrophoresis. The results (Fig. 6) showed the presence of a protein that reacts with the GUS antibodies. This protein has the same molecular mass and isoelectric point as that of the bacterial GUS protein (Fig. 6). Non-transgenic plants presented no signal.

The progeny of the five self-fertilized transgenic plants were screened by GUS histochemical assay and PCR 


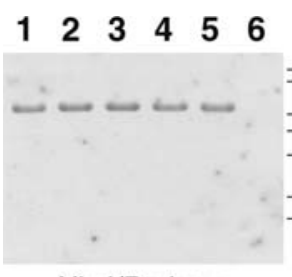

Xbal/Probe a

$\begin{array}{llllll}1 & 2 & 3 & 4 & 5 & 6\end{array}$

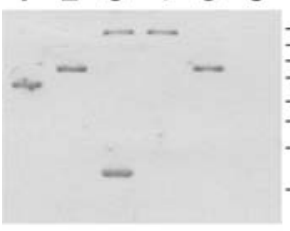

Xbal/Probe b $\begin{array}{llllll}1 & 2 & 3 & 4 & 5 & 6\end{array}$

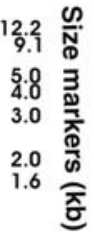

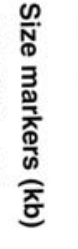

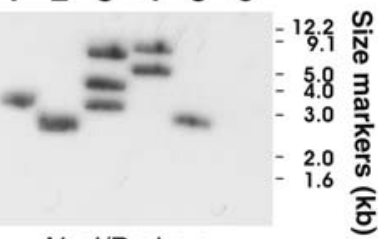

Ncol/Probe a

$\begin{array}{llllll}1 & 2 & 3 & 4 & 5 & 6\end{array}$
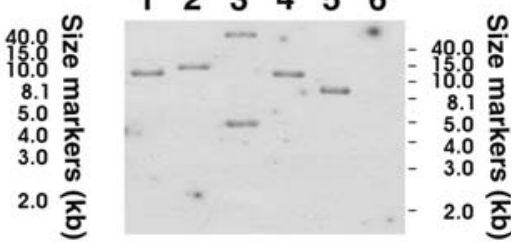

Ncol/Probe b

Fig. 5 Southern blot analysis of putative transformed lines $\left(\mathrm{R}_{0}\right.$ generation). Genomic DNAs were digested with XbaI or NcoI, transferred to a nylon membrane and hybridized with probe 'a' or probe ' $b$ '. Lanes 1-5: Independently transformed lines (line 5.1, line 5.2, line 5.3, line 5.4, line 5.5, respectively). Lane 6 Non-transformed plant. Molecular size markers are indicated on the right

analysis for the presence of the gus and ahas transgenes (Fig. 7). Data revealed that both gus and ahas genes cosegregated in a Mendelian ratio in all transgenic lines. Southern blot analysis confirmed the presence of the ahas expression cassette in the $\mathrm{T}_{1}$ generation (Fig. 7). Four lines presented a ratio of 3:1 (102 positives: 30 negatives, $\chi^{2}=$ $0.36, P=0.54, d f=1$, for line $5.1 ; 233$ positives: 76 negatives, $\chi^{2}=0.01, P=0.86, d f=1$, for line $5.2 ; 167$ positives: 51 negatives, $\chi^{2}=0.29, P=0.58, d f=1$, for line 5.4, and 345 positives: 123 negatives, $\chi^{2}=0.41, P=0.52$, $d f=1$, for line 5.5). One line presented a ratio of 15:1 (243 positives: 17 negatives, $\chi^{2}=0.04, P=0.84, d f=1$, for line 5.3). Transgenic seeds from $T_{1}$ generation were sown and plants were grown to maturity to collect $\mathrm{T}_{2}$ seeds. $\mathrm{T}_{2}$ generation exhibited a segregation of $1: 2: 1$ with a homozygous sub-line (data not shown).

In order to verify the presence of chimerism in primary transgenic plants, the position and distribution of the $T_{1}$ seeds was recorded. Transgenic seeds were randomly distributed in the whole plants and were found in all pods (Fig. 8).

\section{Discussion}

We have developed a novel system to obtain fertile transgenic cowpea plants, which are able to transfer the transgenes in a stable manner to the following generations. It is not time consuming and requires 7-9 months from explant preparation to harvested seeds from the first generation. The system is based on the bombardment of DNA-coated microparticles to introduce foreign genes into apical

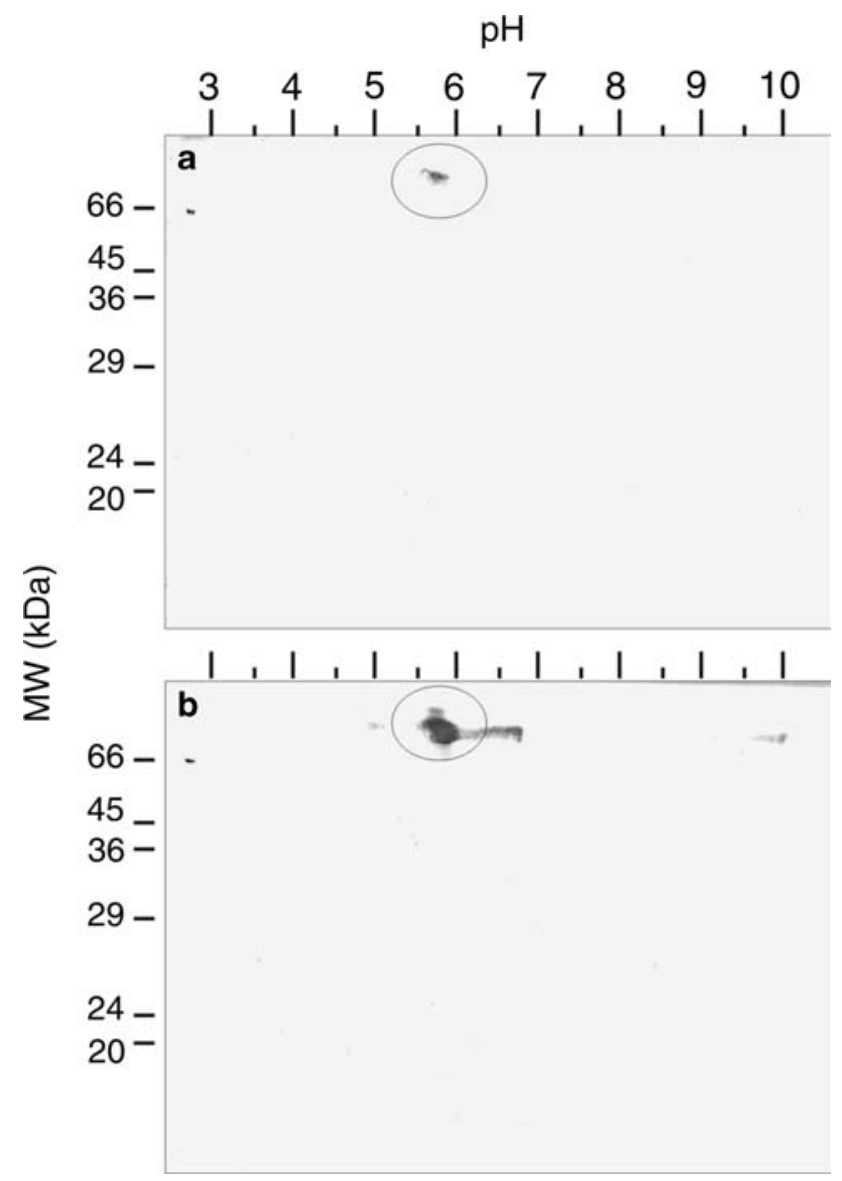

Fig. 6 Western blot analysis of proteins isolated from leaves of transgenic cowpea plants. Total proteins from transgenic plants (a) were fractionated by 2D-electrophoresis and transferred to PVDF membranes; after transfer, membranes were incubated with polyclonal antibodies raised against a synthetic peptide corresponding to amino acids 589-603 at the C-terminus of E. coli GUS protein, followed by incubation with secondary antibodies labeled with alkaline phosphatase. A western blot analysis of a GUS preparation purchased from Sigma-Aldrich is shown in (b)

meristematic cells and selection of the transgenic cells with a herbicide molecule. The herbicide molecule belongs to the imidazolinone class (imazapyr), which is capable of systemically translocating and concentrating in the apical meristematic region of the plant. This selection, coupled with a multiple shooting induction strategy, allowed for the recovery of transgenic cowpea lines at a frequency of germ line transformation that is about sixfold higher than that obtained by Popelka et al. (2006), using an Agrobacteriummediated transformation protocol. Moreover, in our protocol, all explants with elongated shoots were rooted on hormone-free medium. When compared with the Agrobacterium-mediated protocol described by Chaudhury et al. (2007), the system described here gives a slightly higher frequency of transformation. However, our system is based on a simpler tissue culture protocol that does not require 
a

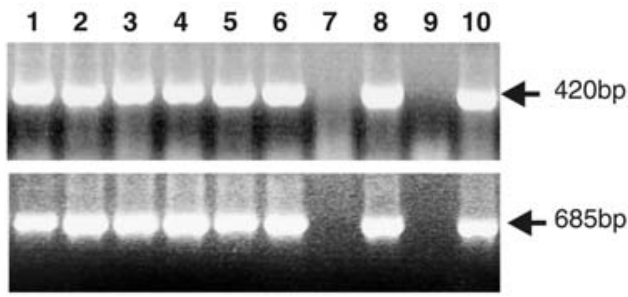

b

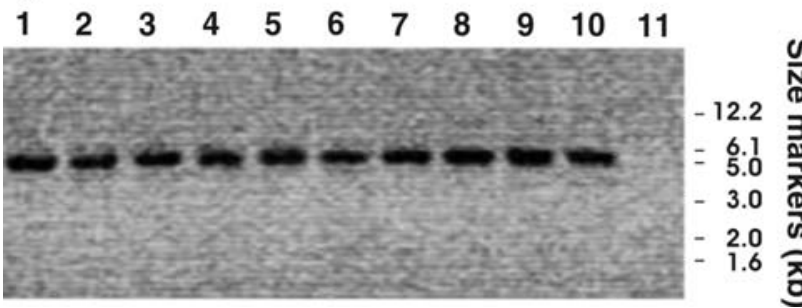

Fig. 7 a PCR analysis of cowpea plants from the $\mathrm{T}_{1}$ generation. Lanes $1-6$ and 8 Transformed plants. Lane 7 Non-transformed segregating plant. Lane 9 non-transformed plant (negative control). Lane 10 positive control (plasmid pAG1). Arrows indicate the expected fragments from gus (upper lanes) and ahas (lower lanes) genes. b Southern blot analysis of transformed lines in the $\mathrm{R}_{1}$ generation. Genomic DNA was digested with $X b a \mathrm{I}$, transferred to a nylon membrane and probed with the ahas promoter (probe a). Lanes 1 and 2 Plants from line 5.1; Lanes 3 and 4 plants from line 5.2; Lanes 5 and 6 Plants from line 5.3; Lanes 7 and 8 plants from line 5.4; Lanes 9 and 10 Plants from line 5.5). Lane 11 Non-transformed plant. Molecular size markers are indicated on the right several cultivation steps as in the existent systems (Ikea et al. 2003; Popelka et al. 2006; Chaudhury et al. 2007) and utilizes mature seeds that do not require elaborate treatments. Moreover, although only the cultivar CE-11 was used for transformation, there is nothing intrinsic to the protocol that would limit its application to other cowpea varieties. In principle, it could be utilized with any cultivar for which a multiple shooting induction has been optimized. Indeed, similar systems have proved their use for several cultivars of soybean, common bean and cotton (Aragão et al. 2000, 2005; Rech et al. 2008). However, to test this hypothesis, other cowpea cultivars should be studied further.

Although no comparative studies have been carried out, it seems that selection with imazapir was more efficient that with other selective agents previously used for cowpea transformation, such as phosphinothricin, kanamycin, geneticin and hygromycin (Penza et al. 1991; Ikea et al. 2003; Popelka et al. 2006). About $38 \%$ of elongated shoots were not transgenic. However, when imazapyr concentration was increased to reduce the number of escapes, no elongated shoots were obtained or the number of transgenic plants was drastically reduced. Similar results were observed for soybean, pea and lentil under selection with herbicide-selective molecules (Aragão et al. 2000; Polowick et al. 2000, Gulati et al. 2002).
Fig. 8 Schematic representation of the distribution of transgenic (solid boxes) and non-transgenic (white boxes) plants (T1 generation) in the transgenic mother plant. The small boxes represent the seeds and a group of boxes represents a pod positioned in the plant

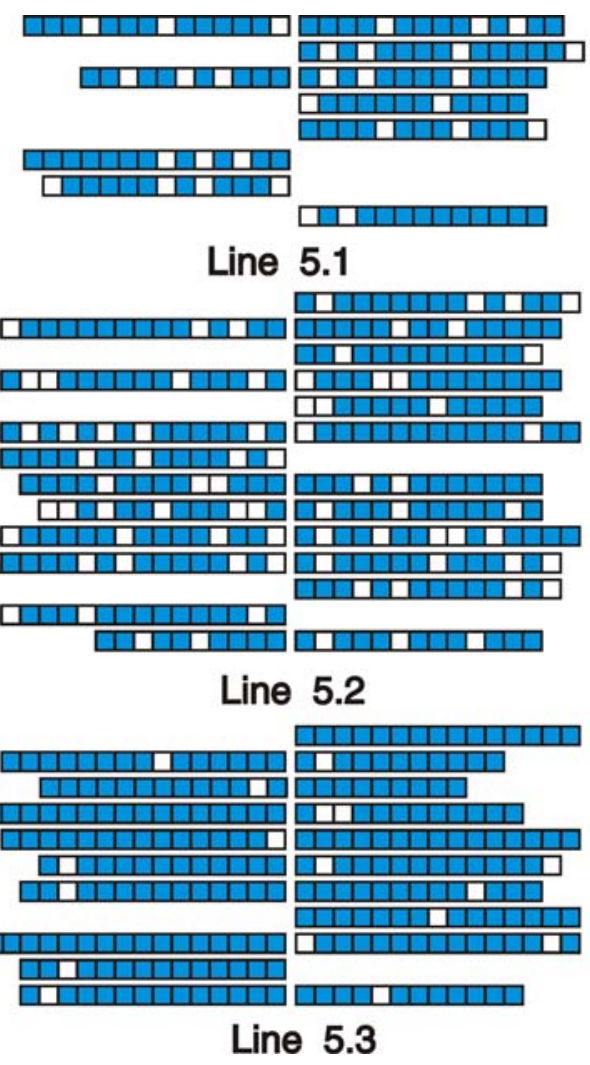

\section{Line 5.4}

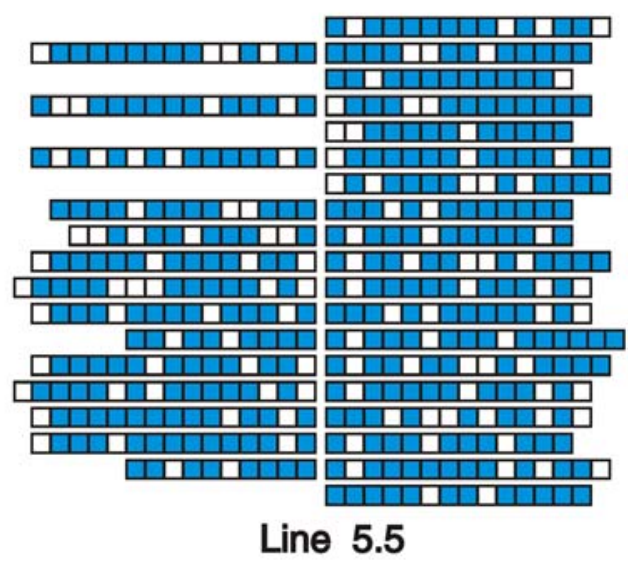


Since our transformation system is based on the bombardment of the apical meristem, it is mandatory to have the meristematic cells exposed to the accelerated DNAcoated microparticles. In all of the embryonic axes of the cultivars analyzed, the apical meristematic region was almost completely covered by the leaf primordia, reducing drastically the number of cells that could be reached by the microparticles, thus impairing the efficiency of transformation. We have faced a similar situation with the common bean, but it was possible to circumvent this drawback by identifying varieties, which had more suitable shoot apex morphologies (Aragão and Rech 1997, 1996). In the present study, as we were unable to find a cowpea cultivar displaying such characteristics, we removed both primary and primordial leaves under a light stereomicroscope to increase the exposure of the shoot apical meristem. However, in order to avoid manipulations such as those reported, we consider it necessary to perform a wider screening in the cowpea germoplasm, to identify a cultivar with a shoot apical meristem region that is more suitable for microparticle bombardment experiments.

The integration of the ahas and gus gene expression cassettes in the cowpea genome was confirmed by Southern blot analysis, which also indicated that most of the transgenic plants harbored a low number of copies of the transgenes. Fragments smaller than $12.0 \mathrm{~kb}$ were observed in the Southern analysis with genomic DNA digested with $N c o I$ and hybridized with the ahas $5^{\prime}$ region. This suggests that for most transgenic lines the circularized vector was broken in the region between the sites for KpnI and SacI during integration. Although the vector is expected to randomly break for integration, it could be explained by the fact that transgenic lines were selected based on concomitant tolerance to imazapyr and gus gene expression. Consequently, lines presenting only the ahas or gus cassette would be eliminated during plant selection. Further analysis, involving the sequencing of the complete integrated loci and probing for different regions, would provide more detailed information on the transgene integration and organization of target sites in the cowpea genome.

Progeny analysis of self-pollinated $T_{1}$ generation transgenic plants revealed that the segregation occurred according to the laws of Mendel, in a ratio of $3: 1$ or 15:1. These data are in agreement with the Southern blot analysis. Lines 5.1, 5.2 and 5.5, which exhibited a segregation ratio of $3: 1$, presented only one copy of the ahas transgene integrated into the plant genome. Line 5.3, which presented three copies of the transgenes, showed a segregation ratio of 15:1, suggesting that the copies are distributed in two loci.

In order to verify the presence of chimerism in the primary transgenic plants, the distribution of the $T_{1}$ seeds was recorded. Transgenic seeds were randomly distributed in all the plants and were present in all pods. This suggests that primary transgenic cowpea lines were not chimeric. We have previously showed that selection with imazapyr would reduce the possibility of chimerism in soybean and cotton plants (Aragão et al. 2000, 2005; Rech et al. 2008).

Biotechnological tools to complement traditional breeding may facilitate the generation of new varieties carrying genes with desired agronomic traits that are difficult to find in primary or secondary genepools. We have established a higher-frequency genetic transformation system for cowpea that will be of particular importance for functional genomic studies as well as for the practical application of genetic engineering to introduce important traits such as pest resistance into this important legume.

Acknowledgments This work was supported by Embrapa, Renorbio (Renorbio - Rede Nordeste de Biotecnologia) and CNPq/MCT. The authors would like to thank Dr. Francisco Rodrigues Freire Filho (Embrapa Meio Norte, Brazil) for providing the cowpea seeds and Dr. Michael Richardson for reading the manuscript.

\section{References}

Akella V, Lurquin PF (1993) Expression in cowpea seedlings of chimeric transgenes after electroporation into seed-derived embryos. Plant Cell Rep 12:110-117. doi:10.1007/BF00241945

Aliyu B (2007) Heritability and gene effects for incorporating pubescence into cowpea (Vigna unguiculata (L) Walp.) from V. rhomboidea Burtt. Davy. Euphytica 155:295-303. doi:10.1007/ s10681-006-9331-0

Aragão FJL, Campos FAP (2007) Common bean and cowpea. In: Pua EC, Davey MR (eds) Biotechnology in agriculture and forestry. Transgenic crops IV. Springer, Berlin, pp 263-276

Aragão FJL, Rech EL (1997) Morphological factors influencing recovery of transgenic bean plants (Phaseolus vulgaris L.) of a carioca cultivar. Int J Plant Sci 158:157-163. doi:10.1086/ 297426

Aragão FJL, Barros LMG, Brasileiro ACM, Ribeiro SG, Smith FD, Sanford JC, Faria JC, Rech EL (1996) Inheritance of foreign genes in transgenic bean (Phaseolus vulgaris L.) co-transformed via particle bombardment. Theor Appl Genet 93:142-150. doi: 10.1007/BF00225739

Aragão FJL, Sarokin L, Vianna GR, Rech EL (2000) Selection of transgenic meristematic cells utilizing a herbicidal molecule results in the recovery of fertile transgenic soybean (Glycine max (L.) Merril) plants at high frequency. Theor Appl Genet 101:1-6. doi: $10.1007 /$ s001220051441

Aragão FJL, Vianna GR, Carvalheira SBRC, Rech EL (2005) Germ line genetic transformation in cotton (Gossypium hirsutum L.) by selection of transgenic meristematic cells with a herbicide molecule. Plant Sci 168:1227-1233. doi:10.1016/j.plantsci.2004.12.024

Bradford M (1976) A rapid and sensitive method for the quantitation of microgram quantities of protein utilizing the principle of protein-dye binding. Anal Biochem 72:248-254

Chaudhury D, Madanpotra S, Jaiwal R, Saini R, Kumar AP, Jaiwal PK (2007) Agrobacterium tumefaciens-mediated high frequency genetic transformation of an Indian cowpea (Vigna unguiculata L. Walp.) cultivar and transmission of transgenes into progeny. Plant Sci 172:692-700. doi:10.1016/j.plantsci.2006.11.009

Edwards K, Johnstone C, Thompson C (1991) A simple and rapid method for the preparation of plant genomic DNA for PCR analysis. Nucleic Acids Res 19:1349. doi:10.1093/nar/19.6.1349 
Fang J, Chao CT, Roberts PA, Ehlers JD (2007) Genetic diversity of cowpea [Vigna unguiculata (L.) Walp.] in four West African and USA breeding programs as determined by AFLP analysis. Genet Resour Crop Evol 54:1197-1209. doi:10.1007/s10722-006-9101-9

FAOSTAT (2006) FAO agriculture database. FAO, Rome. Available at http://faostat.fao.org/faostat

Garcia JA, Hille J, Goldbach R (1986) Transformation of cowpea (Vigna unguiculata) cells with an antibiotic-resistance gene using a Ti-plasmid-derived vector. Plant Sci 44:37-46. doi: 10.1016/0168-9452(86)90166-4

Garcia JA, Hille J, Vos P, Goldbach R (1987) Transformation of cowpea (Vigna unguiculata) with a full-length DNA copy of cowpea mosaic virus M-RNA. Plant Sci 48:89-98. doi: 10.1016/0168-9452(87)90135-X

Gomathinayagam P, Ganesh ram S, Rathnaswamy R, Ramaswamy NM (1998) Interspecific hybridization between Vigna unguiculata (L.) Walp. and V. vexillata (L.) A. Rich through in vitro embryo culture. Euphytica 102:203-209. doi:10.1023/A: 1018381614098

Gulati A, Schryer P, Mchughen A (2002) Production of fertile transgenic lentil (Lens culinaris Medik) plants using particle bombardment. In vitro Cell Dev Biol Plant 38:316-324. doi: 10.1079/IVP2002303

Ikea J, Ingelbrecht I, Uwaifo A, Thotttappilly G (2003) Stable gene transformation in cowpea (Vigna unguiculata L. Walp.) using particle gun method. Afr J Biotechnol 2:211-218

Jefferson RA (1987) Assaying chimeric genes in plants: the GUS gene fusion system. Plant Mol Biol Rep 5:387-405. doi:10.1007/ BF02667740

Murdock LL (1992) Improving insect resistance in cowpea through biotechnology. In: Thottappilly G, Monti LM, Mohan Raj DR, Moore AW (eds) Biotechnology: enhancing research on tropical crops in Africa. CTA-IITA, pp, pp 313-320

Muthukumar B, Mariamma M, Veluthambi K, Gnanam A (1996) Genetic transformation of cotyledon explants of cowpea (Vigna unguiculata L. Walp) using Agrobacterium tumefaciens. Plant Cell Rep 15:980-985. doi:10.1007/BF00231600

Obatolu VA (2003) Growth pattern of infants fed with a mixture of extruded malted maize and cowpea. Nutrition 19:174-178. doi: 10.1016/S0899-9007(02)01102-4
Penza R, Lurquin PF, Filippone E (1991) Gene transfer by cocultivation of mature embryos with Agrobacterium tumefaciens - application to cowpea (Vigna unguiculata Walp). J Plant Physiol 138:39-43

Penza R, Akella V, Lurquin PF (1992) Transient expression and histological localization of a gus chimeric gene after direct transfer to mature cowpea embryos. Biotechniques 13:576-580

Phillips RD, McWatters KH, Chinnan MS, Hung Y-C, Beuchat LR, Sefa-Dedeh S, Sakyi-Dawson S-D, Ngoddy P, Nnanyelugo D, Enwere J, Komey NS, Liu K, Mensa-Wilmot Y, Nnanna IA, Okeke C, Prinyawiwatkul W, Saalia FK (2003) Utilization of cowpeas for human food. Field Crops Res 82:193-213. doi: 10.1016/S0378-4290(03)00038-8

Polowick PL, Quandt J, Mahon JD (2000) The ability of pea transformation technology to transfer genes into peas adapted to western Canadian growing conditions. Plant Sci 153:161-170. doi:10.1016/S0168-9452(99)00267-8

Popelka JC, Gollasch S, Moore A, Molvig L, Higgins TJV (2006) Genetic transformation of cowpea (Vigna unguiculata L.) and stable transmission of the transgenes to progeny. Plant Cell Rep 25:304-312. doi:10.1007/s00299-005-0053-x

Rech EL, Vianna GR, Aragão FJL (2008) High efficiency transformation by biolistics of soybean, common bean and cotton transgenic plants. Nat Protoc 3:410-418. doi:10.1038/nprot. 2008.9

Sambrook J, Russell DW (2001) Molecular cloning: a laboratory manual, 3rd edn. Cold Spring Harbor Laboratory Press, Cold Spring Harbor, NY, USA

Somers DA, Samac DA, Olhoft PM (2003) Recent advances in legume transformation. Plant Physiol 131:892-899. doi: $10.1104 / \mathrm{pp} .102 .017681$

Steel RGD, Torrie JH (1980) Principles and procedures of statistics. McGraw-Hill, New York

Taiwo MA, Kareem KT, Nsa IY, Hughes JD (2007) Cowpea viruses: Effect of single and mixed infections on symptomatology and virus concentration. Virol J 4:95. doi:10.1186/1743-422X-4-95

Vasconcelos EAR, Nogueira FCS, Abreu EFM, Gonçalves EF, Souza PAS, Campos FAP (2005) Protein extraction from cowpea tissues for 2D electrophoresis and MS analysis. Chromatographia 62:447-450. doi:10.1365/s10337-005-0637-1 